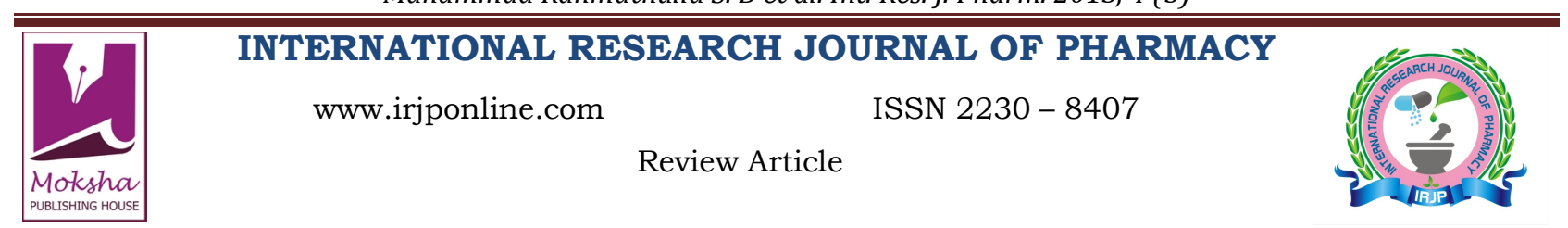

\title{
ORIGINATION AND DEVELOPMENT OF ISOPROTERENOL-INDUCED MYOCARDIAL INFARCTION IN MALE WISTAR RATS
}

\author{
Mahammad Rahmathulla S. B ${ }^{1}$, Kodidhela Lakshmi Devi ${ }^{2 *}$ \\ ${ }^{1}$ Department of Biochemistry, Sri Krishnadevaraya University, Anantapuramu, India \\ ${ }^{2}$ College of Medicine and Health Sciences, Department of Biochemistry, Gondar University, Gondar, Ethiopia \\ *Corresponding Author Email: klakshmidevi.bio@gmail.com
}

Article Received on: 17/03/13 Revised on: 21/04/13 Approved for publication: 11/05/13

DOI: $10.7897 / 2230-8407.04508$

IRJP is an official publication of Moksha Publishing House. Website: www.mokshaph.com

(C) All rights reserved.

\section{ABSTRACT}

Cardiovascular disease is considered the major cause of morbidity and mortality throughout the world. Catecholamines (epinephrine, norepinephrine and isoproterenol) and their oxidation products cause a direct toxic effect on the myocardium. They exert a receptor-mediated effect on the myocardium. Isoproterenol is a synthetic catecholamine that simulates the actions of sympathetic nervous system (SNS) activation on the heart. Chronic isoproterenol administration produces a rapid, highly reproducible rodent model of cardiac hypertrophy. Isoproterenol infusion impaired in vivo cardiac function, induced hypertrophy and decreased both fatty acid and glucose metabolism, changes similar in direction and magnitude to those found in the rat heart following moderate severity myocardial infarction. With the use of small animal disease models in preclinical research, workers have acquired a large amount of information on the pathogenesis/progression of cardiovascular disease, which has aided the development of effective treatment options. These animal models are effective scientific tools to study the molecular mechanisms of cardiovascular diseases, which potentially provide a powerful approach for discovering new drugs.

Keywords:Pathogenesis of Catecholamine-Induced Cardiomyopathy, Isoproterenol, Mechanisms, Hypoxia and Hemodynamic Changes, Coronary Spasms and Hemodynamic, Biochemical Changes, Electrolyte shift and $\mathrm{ca}^{2+}$ over load, Membrane changes and Histological changes.

\section{INTRODUCTION}

Heart disease is a major public health problem in the United States. Every year, approximately 715,000 persons in the United States have a heart attack, and approximately 600,000 die from heart disease. Heart disease is the leading cause of death for U.S. men and women, accounting for one out of every four deaths each year ${ }^{1}$. Cardiovascular disease, in most European countries around $40 \%$ of all-cause mortality is attributable to this spectrum of illness ${ }^{1 \mathrm{~A}}$. Cardiovascular disease is the leading cause of death in both men and women $^{2}$. Sudden cardiac arrest accounts for many of these deaths. Population-based reports of emergency medical services 'experience from the United States of America give survival estimates of approximately $8 \%{ }^{3}$. The adrenergic receptors in the heart that are stimulated by catecholamines are the $\alpha$-adrenoceptors and $\beta$-adrenoceptors $\left(\beta_{1}\right.$ and $\left.\beta_{2}\right)$; however, the $\beta_{2}$-adrenoceptors are found chiefly in extracardiac sites, such as arterioles, where they cause dilation. On the other hand, the $\alpha$-adrenoceptors present in the vascular smooth muscle are mainly concerned with the maintenance of blood vessel tone. SNS activation results in increased cardiac contraction, increased heart rate, increased systolic blood pressure and decreased diastolic pressure. Catecholamines at low concentrations are beneficial in regulating heart function by exerting a positive inotropic action on the myocardium ${ }^{4}$, whereas high concentrations of catecholamines or chronic exposure to catecholamines over a prolonged period produce deleterious effects on the cardiovascular system. It has been known for many years that epinephrine, norepinephrine, and isoproterenol cause cardiac hypertrophy and/or myocardial lesions ${ }^{5-8}$. The lesions caused by epinephrine, norepinephrine, and isoproterenol were qualitatively similar, but the lesions that were seen after isoproterenol treatment were more severe than those produced by epinephrine or norepinephrine ${ }^{9,10 .}$ In fact, isoproterenol was found to be 29 to 72 times more potent in producing myocardial lesions of equal severity than epinephrine or norepinephrine. Large doses of exogenously administered norepinephrine in humans and animals were observed to produce myocardial lesions that include focal necrosis and degeneration as well as mononuclear leukocytic infiltration ${ }^{11}$. Typical pathological findings of catecholamineinduced myocardial damage are hypertrophy and contraction band necrosis of myofibers accompanied by a moderate inflammatory reaction; fibrous replacement of the myocardium cans sometimes occur ${ }^{12}$. These myocardial lesions and damage are considered to represent "catecholamine-induced myocardial cell damage," "catecholamine induced myocarditis or myocardial infarction (MI) and are now designated as "catecholamine-induced cardiomyopathy." The activation of SNS has been observed in patients suffering from acute $\mathrm{MI}$ as well as during percutaneous transluminal coronary angioplasty; the levels of catecholamines were found to correlate with the degree of injury. Catecholamine-induced cardiomyopathy is also associated with several pathological conditions such as pheochromocytoma ${ }^{13-15}$, subarachnoid haemorrhage, and various other intracranial lesions ${ }^{16-19}$ as well as following electrical stimulation of the stellate ganglion $^{20,21}$ or hypothalamus $^{22}$ in experimental animals showing high levels of plasma catecholamines. These studies not only demonstrate that catecholamines are capable of producing myocardial necrosis but also suggest that myocardial cell damage seen in patients may be the result of high levels of circulating catecholamines for a prolonged period. It should be pointed out that reversible catecholamine-induced cardiomyopathy has also been reported ${ }^{23-27}$. Catecholamines are known to produce a wide variety of direct and indirect pharmacological actions on cardiovascular hemodynamics and metabolism. As a consequence of these complex effects, it has been difficult to determine whether catecholamines exert a direct toxic influence on the myocardium or whether myocardial cell damage is in some way secondary to other actions of catecholamines ${ }^{28-33}$. Up until now, several 
mechanisms such as cardiovascular hemodynamic and metabolic changes, alterations in the sarcolemmal (SL) permeability, formation of oxidation products of catecholamines, and accumulation of catecholamine metabolites during the monoamine oxidase (MAO) reaction are thought to be involved in the pathogenesis on catecholamine induced cardiomyopathy ${ }^{34-46}$. Although there is no clear-cut implication of any one of these mechanisms, an attempt has been made in this review to formulate a unifying concept regarding the pathophysiology and clinical significance of catecholamine-induced cardiomyopathy.

\section{Induction of Cardiomyopathy}

Administration of isoproterenol depletes the energy reserve of cardiac muscle cells and causes complex biochemical and structural changes that eventually lead to cell damage and necrosis ${ }^{47}$. Isoproterenol can also cause severe oxidative stress in the myocardium, resulting in infarct-like necrosis of the heart myocardium. In fact, it was discovered that relatively low and nonlethal doses of isoproterenol can cause severe myocardial necrosis ${ }^{48}$ Although the $\mathrm{LD}_{50}$ of isoproterenol in rats was reported to be $680 \mathrm{mg} / \mathrm{kg}$, doses as low as $0.02 \mathrm{mg} / \mathrm{kg}$ were observed to produce microscopic focal necrotic lesions. The severity of myocardial damage was closely related to the dosage of isoproterenol used and varied from focal lesions affecting single cells to massive infarcts involving large portions of the myocardium. Isoproterenol-induced myocardial lesions were generally found to be localized in the apex as well as in the LV subendocardium and were observed less frequently in the papillary muscle and the right ventricle. Isoproterenol was also found to produce apical lesions and disseminated focal necrosis ${ }^{49}$; however, these lesions were frequently fatal and the median lethal dosage was much lower. Isoproterenol has been observed to produce a number of biochemical or electrophysiological alterations, which precede the histopathological changes in the heart. It is believed that isoproterenol-induced myocardial necrosis is related to altered myocardial energy generation, which may be related to $\mathrm{Ca}^{2+}$-overload. $\mathrm{Ca}^{2+}$-influx after isoproterenol in rats shows two phases: a rapid process occurring immediately, followed by a delayed slower influx of $\mathrm{Ca}^{2+}$. The initial phase is associated with histopathological alterations of the myocardium (mitochondrial swelling and Z-disk thickening due to hypercontraction). Thus, the initial phase is thought to be the key event during isoproterenol-induced myocardial necrosis ${ }^{50}$. Another study suggests that there are three stages of isoproterenol-induced cardiotoxicity: preinfarction, which occurs before 12 hours; infarction, which occurs from 12 to 24 hours; and postinfarction, which occurs after 24 hours following isoproterenol admistration ${ }^{51}$. 17- $\beta$-Estradiol inhibited the stimulatory action of isoproterenol on $\mathrm{Ca}^{2+}$ influx via the L-type $\mathrm{Ca}^{2+}$ channel in the ventricular myocytes. This inhibition may lead to reductions in the heart rate and contraction, therefore reducing oxygen consumption and producing cardioprotection ${ }^{52}$. Estrogen also inhibited the augmented cyclic adenosine monophosphate (cAMP) production on isoproterenol administration. ${ }^{53}$ When $\mathrm{Ca}^{2+}$ influx was inhibited, there was only a reduction in isoproterenol myocardial necrosis, suggesting factors other than $\mathrm{Ca}^{2+}$ may be involved. Isoproterenol can also increase the levels of serum and myocardial lipids, leading to coronary heart disease $\mathrm{e}^{54}$ and stimulate lipid peroxidation, leading to irreversible damage to the myocardial membrane. Specifically, damage to the myocardium could be due to the induction of free radical-mediated lipid peroxidation. Recently, some studies have shown that certain treatments may improve the negative effects of isoproterenol. For example, pretreating isoproterenol cardiotoxic hearts with naringin, a predominant flavanone found in grapefruit, significantly decreased the levels of thiobarbituric acidreactive substances and cardiac tissue lipid peroxides in plasma and heart, in addition to increased activities of superoxide dismutase (SOD), catalase, reduced glutathione (GSH), GSH-dependent enzymes glutathione peroxidase (GPx) and glutathione-S-transferase (GST) in the heart. Isoproterenol also decreased the levels of antioxidants, vitamin $\mathrm{C}$ and vitamin $\mathrm{E}$; however, pretreatment with naringin increased the antioxidant levels. In one study, isoproterenol was observed to induce GSH oxidation and conjugation, but this effect decreased at sub physiological $\mathrm{Ca}^{2+}$ concentrations. Simultaneous incubation with copper increased isoproterenol oxidation and GSH oxidation but decreased GSH conjugation ${ }^{55}$. Vitamin $C^{56,57}$ has shown protection from myocardial lipid peroxidation, and likewise, vitamin $\mathrm{E}$ pretreatment protected the myocardium against isoproterenol-induced injury ${ }^{58}$ In another study, Sallycysteine lowered the lipid peroxidation end products and increased the levels of SOD, catalase, GSH, GPx, GST, and ascorbic acid. Also, mangiferin, a pharmacologically active phytochemical has demonstrated hypolipidemic activity in isoproterenol-induced rats. Isoproterenol was shown to result in diffuse areas of fibrosis; however, when treated with phenytoin, the fibrosis was less severe ${ }^{59}$. Some studies have shown a marked increase in cholesterol, free fatty acids, and TGs in both serum and heart in isoproterenol-induced cardiomyopathy; aspirin showed a marked reversal of these metabolic changes induced by isoproterenol ${ }^{60}$. Isoproterenol can also produce an accumulation of neutral fat droplets in the sarcoplasm; $\gamma$-hydroxybutyrate either abolished or reduced the accumulation of fat and completely prevented myofiber death ${ }^{61}$. In isoproterenol-treated rats, there was a decrease in diagnostic marker enzymes of MI, which are creatine kinase, lactate dehydrogenase (LDH), aspartate transaminase, alanine transaminase; this change may be due to membrane leakage caused by isoproterenol-induced damage to the SL membrane. Oral S-allycysteine administration restored these activities in isoproterenol treated rats. From these studies, it appears that the isoproterenol-induced cardiomyopathy may be due to oxidative stress and free radical damage, myocardial hypoperfusion, glycogen depletion, electrolyte imbalance and lipid accumulation.

\section{Mechanisms of Isoproterenol-Induced Cardiomyopathy}

Although excessive amounts of circulating catecholamines are known to induce cardiomyopathy, the mechanisms are not clearly understood. Various theories have been proposed to suggest the cause and mechanisms for the development of catecholamine-induced cardiomyopathy. The major hypotheses include: (i) a relative cardiac hypoxemia due to increased cardiac work and myocardial oxygen demands, aggravated by hypotension in the case of isoproterenol ${ }^{49}$ (ii) coronary arterial vasoconstriction (spasm) causing endocardial ischemia ${ }^{30}$ (iii) inadequate perfusion of the endocardium due to impaired venous drainage of the heart ${ }^{62}$; (iv) hypoxia due to direct oxygen-wasting effects of catecholamines or their oxidation products ; (v) interference with mitochondrial oxidative phosphorylation by free fatty $\operatorname{acids}^{63,64 ;}$ (vi) occurrence of intracellular $\mathrm{Ca}^{2+}$-overload due 
to massive calcium influx; (vii) formation of adrenochromes and other oxidation products including oxyradicals ${ }^{65}$; (viii) potassium depletion ${ }^{66}$ and altered permeability of the myocardial cell membrane through elevation of plasma nonesterified-free fatty $\operatorname{acids}^{67}$; and, (ix) depletion of intracellular magnesium required for many ATP-dependent enzymatic processes ${ }^{68}$. This section is devoted to discussion of different mechanisms, which have been suggested to explain the cardiotoxic effects of isoproterenol.

\section{Hypoxia and Hemodynamic Changes}

It was found that both high and low doses of isoproterenol increased heart rate similarly but the cardiac lesionproducing doses of isoproterenol resulted in a fall in blood pressure. It was suggested that the fall in aortic blood pressure was of such a degree that a reduced coronary flow could be inferred. It was further postulated that the necrotic lesions are the ischemic infarcts due to a decreased coronary flow during a time when both amplitude and frequency of cardiac contractions are increased. Thus, the greater damage to myocardium by isoproterenol as compared with epinephrine or norepinephrine was attributed to the dramatic hypotension. Various factors, such as previous myocardial damage, previous isoproterenol injections, or activation of metabolic processes were considered to provide cardiac muscle cells with an adaptation to withstand the increased oxygen demand and relative hypoxia produced by isoproterenol $^{69}$. On the other hand, it was found that dlephedrine and d-amphetamine produced lesions in less than $50 \%$ of animals, although these agents increase blood pressure, while ephedrine and amphetamine have a positive inotropic effect ${ }^{37}$. Accordingly, it was suggested that drugs with both positive inotropic and chronotropic actions might not produce cardiac lesions. In fact, methoxamine which has no positive inotropic effect was found to produce cardiac lesions. In another study ${ }^{38}$, the hemodynamic effects of "pharmacologic" and lesion-producing doses of sympathomimetics were compared. It was found that lesionproducing doses of isoproterenol decreased aortic flow and heart rate as compared with pharmacological doses, but these were still above the control values. Stroke work was greater with lesion-producing doses as compared with pharmacological doses, but the mean aortic pressure, which determines the coronary perfusion pressure, was not reduced by the lesion-producing doses of isoproterenol. Thus, there is evidence of impaired function of the myocardium but the hemodynamic change does not appear adequate to produce insufficient myocardial perfusion. As a result of these findings, it was suggested that the effects of isoproterenol were due to some direct action on the myocardial cell and not solely due to the hemodynamic effects. Furthermore, the coronary flow could not have been greatly reduced by isoproterenol because the blood pressure remained above that in shock and the cardiac output was increased ${ }^{34}$ and thus it was concluded that hypotension is nonessential for the production of cardiac necrosis by isoproterenol. This view was supported by the finding that verapamil was effective in protecting the heart from isoproterenol-induced necrosis even though blood pressure fell almost twice as much when verapamil was administered together with isoproterenol as it did following administration of isoproterenol alone $\mathrm{e}^{70}$

\section{Coronary Spasms and Hemodynamic Effects}

Another hypothesis closely related to that of coronary insufficiency of hemodynamic origin is that of a relative ischemia resulting from coronary vascular changes. It was found that isoproterenol changed the distribution of uniform coronary flow in the endomyocardium ${ }^{30}$. These results suggest that dilatation of arteriovenous shunts might be responsible for the endocardial ischemia because coronary flow is usually increased with isoproterenol. On the other hand, a marked occlusion of coronary vessels was observed in $69 \%$ of animals at 30 minutes and $33 \%$ of animals at 60 minutes, but almost no occlusion was seen at 24 hours following isoproterenol injection ${ }^{71}$. It was thought that these results occurred due to spasm of the coronary vessels. Changes in peripheral resistance due to catecholamines were also important because it was possible to reproduce essentially similar pathological changes by surgical occlusion of the efferent vessels ${ }^{62}$. On this basis it was suggested that impairment of venous drainage via venospasm largely accounts for the adverse effects of catecholamines. Blood flow to the LV subendocardial muscle has been suggested to be compromised during systole and to occur mainly during diastole because intramyocardial compressive force is greatest in this region ${ }^{72,73}$. Furthermore, it has been shown ${ }^{74}$ that when aortic diastolic pressure was lowered or diastole shortened (by pacing) and myocardial oxygen demands simultaneously rose, myocardial performance was found to be impaired. Scintillation counting of the distribution of ${ }^{141} \mathrm{Ce}-,{ }^{85} \mathrm{Sr}$-, or ${ }^{46} \mathrm{Sc}$-labeled microspheres was used to determine the coronary flow distribution during isoproterenol infusion $^{75}$. When isoproterenol was infused at a rate, which failed to maintain the increase in contractile force, it was found that subendocardial flow fell by 35\%, while subepicardial flow increased by $19 \%$. Thus, although spasm of coronary arteries and/or veins may well occur, it is possible that increased cardiac activity, reduced aortic pressure, and greatly decreased diastole could also be responsible for an under perfusion of the endocardium. A serious challenge to the concept of impaired ventricular perfusion as the primary cause of necrosis was presented by employing the $85 \mathrm{Kr}$ clearance method to study perfusion of the ventricle during epinephrine infusion ${ }^{36}$. Evidence of myocardial necrosis was obtained 75 minutes after the start of epinephrine infusion but $85 \mathrm{Kr}$ clearance studies showed no difference in the rate of clearance from inner, middle, and outer layers of the left ventricle in either the control or epinephrine-treated hearts. Thus, there was no evidence for ischemia of subendocardial tissue as a causal factor in the epinephrine-induced necrosis. On the other hand a decreased passage of the trace substance horseradish peroxidase from the capillaries to the myocardial interstitium was observed in a study in which isoproterenol was infused at a low concentration $^{28 .}$ Thus, this controversy still remained to be resolved. The hypothesis that the vascular factors are the primary cause of necrotic lesions was also tested using the turtle heart as a unique model in which perfusion of the endocardium is not vascular ${ }^{35}$. In the turtle heart, the internal spongy musculature is supplied by diffusion from the ventricular lumen via intertrabecular spaces, while the outer compact layer is supplied by the coronary artery branching off the aorta. Isoproterenol injections were found to produce necrotic lesions in the spongy layer of the turtle heart, which does not support the concept that isoproterenol-induced cardiac necrosis is due to a vascular mechanism.

\section{Biochemical Changes}

It was pointed out that the catecholamine-induced myocardial necrosis must be considered to be of a mixed pathogenesis 
involving both direct metabolic actions in the cardiac muscle as well as factors secondary to vascular and hemodynamic effects ${ }^{76 .}$ Cardiac lesions due to epinephrine and isoproterenol are of a mixed type in which both hypoxias secondary to vascular and hemodynamic effects as well as direct metabolic effects in the heart muscle have a role in their development. It is not, then, unreasonable to regard vascular and hemodynamic effects as complicating factors, which greatly aggravate some more direct toxic influence of catecholamines on myocardial cells. Accordingly, it can be readily understood how a reduction in the extent and severity of catecholamine-induced lesions is brought about by interventions, which specifically block the peripheral vascular change, prevent the positive inotropic and chronotropic effects of these drugs on the heart, or improve the delivery of oxygen to the myocardium. Many years ago $\mathrm{Raab}^{44}$ attributed the cardio toxic actions of catecholamines to their oxygen-wasting effect. According to him: "The most conspicuous reaction of myocardial metabolism to the administration of adrenaline is an intense enhancement of local oxygen consumption which, in certain dosages, by far exceeds the demand of simultaneously increased myocardial muscular work, and which is only partially compensated by a simultaneous increase of coronary blood flow. In this respect adrenaline is able, so to speak, to mimic the anoxiating effects of coronary insufficiency in the absence of any real coronary anomaly. It should be emphasized, however, that the tissue anoxia resulting from the administration of adrenaline is probably not caused by adrenaline itself but by an oxidation product of adrenaline (Bruno Kisch's omega), which acts as an oxidation catalyst even in very high dilutions." It was found that identical electrocardiographic changes occurred during cardiac sympathetic nerve stimulation, electrically induced muscular exercise, or intravenous injection of norepinephrine or epinephrine, when coronary artery dilatability is impaired and during exogenous anoxia or partial occlusion of the coronary arteries ${ }^{77}$. This was taken as evidence that the increased $\mathrm{O}_{2}$ consumption caused by catecholamines produced a relative hypoxia if coronary flow could not be sufficiently increased. A crucial point in the concept of oxygen wasting concerns the origin of the increased $\mathrm{O}_{2}$ consumption with catecholamines - whether it is due to a decreased efficiency of oxygen use or an increased oxygen demand. It was found that the oxygen consumption of resting papillary muscle was not increased by catecholamines even in concentrations 10 times higher than those effective in stimulating $\mathrm{O}_{2}$ consumption of contracting papillary muscles ${ }^{78}$. This study concluded that the increased $\mathrm{O}_{2}$ consumption of the intact heart following administration of epinephrine or norepinephrine is secondary to the increased contractility. On the other hand, it was reported that low dose norepinephrine exerted a maximal inotropic effect with little or no increase of $\mathrm{O}_{2}$ consumption, while larger doses had no further inotropic effect but did increase $\mathrm{O}_{2}$ consumption, indicating that it is excessive catecholamine concentrations which cause oxygen wasting ${ }^{79}$. It was observed that the increase of $\mathrm{O}_{2}$ consumption of the potassium arrested heart caused by catecholamines was $5 \%$ to $20 \%$ of that found in the beating heart ${ }^{80}$; this study concluded that most, but not all, of the increased $\mathrm{O}_{2}$ consumption was secondary to hemodynamic alterations and increased cardiac work. In a similar comparison of the effects of epinephrine on $\mathrm{O}_{2}$ consumption in beating and arrested hearts, it was found that about one-third of the increment in $\mathrm{O}_{2}$ consumption in beating hearts was accounted for by a metabolic effect dissociable from the increased work ${ }^{81 .}$ Furthermore, it was reported that this effect could be blocked by dichloro isoproterenol but not by phentolamine ${ }^{82}$. From these studies it is evident that catecholamines can cause an increase in $\mathrm{O}_{2}$ consumption that is not related to increase cardiac work or activity and the concept of decreased efficiency or oxygen wasting is therefore justified. It has been suggested that this oxygen-wasting effect was actually due to an oxidation product of epinephrine ${ }^{44}$ and one such oxidation product, adrenochrome, was shown to uncouple mitochondria ${ }^{83}$. The uncoupling of mitochondria by adrenochrome was antagonized by GSH in high concentration, probably due to a direct reduction of adrenochrome, since the characteristic red colour of adrenochrome was lost when GSH was added in the presence or absence of mitochondria, whereas oxidized GSH did not affect this uncoupling by adrenochrome. It was found the $\mathrm{P}: \mathrm{O}$ ratio of heart mitochondria by norepinephrine, epinephrine, or isoproterenol was significantly low ${ }^{45}$. RCI and $\mathrm{Q} \mathrm{O}_{2}$ were similar to control, but unfortunately the control RCI values in these experiments were very low. A good relationship between elevation of myocardial catecholamine content and depression of $\mathrm{P}: \mathrm{O}$ ratio in mitochondria was observed. Whereas propranolol pretreatment enhanced the increase in myocardial catecholamines and caused a more marked depression of mitochondrial P:O ratios, dibenzyline and reserpine inhibited both the increase in catecholamine contents and the decrease in the mitochondrial P:O ratio. Since catecholamines under in vitro conditions did not affect the $\mathrm{P}: \mathrm{O}$ ratio of mitochondria at a concentration of $1 \mathrm{mM}$, it was concluded that this was not a direct action of the catecholamines on the mitochondria, but instead adrenochrome or one of its metabolites might be responsible for the observed effect. Some biochemical changes in catecholamine-induced cardiomyopathy. Glycogen content of the heart decreased rapidly after an injection of isoproterenol and then rose above control level during subsequent five hours. Serum glutamate-oxaloacetate transaminase (GOT), aspartate aminotransferase (AST), glutamate-pyruvate transaminase (GPT), LDH, and creatine phosphokinase (CPK) were all greatly elevated during the acute phase of necrotization following catecholamine administration $^{45}$. In one experiment studying the oxidative phosphorylation of heart mitochondria from isoproterenoltreated rats revealed that the RCI was reduced without affecting the $\mathrm{P}: \mathrm{O}$ ratio $^{62}$ It is not possible to draw any definite conclusions from these studies with respect to the effects of catecholamines on mitochondrial respiration, although uncoupling of oxidative phosphorylation is certainly indicated and would explain both the oxygen-wasting effect and the depletion of myocardial high-energy phosphate stores caused by large doses of catecholamines. Having found that heart mitochondria from catecholamine-treated rats were uncoupled, the level of free fatty acids in the mitochondria was determined because free fatty acids are known to uncouple mitochondria ${ }^{45}$. No difference in mitochondrial-free fatty acid content or composition was found and it was concluded that the observed uncoupling might not be due to the accumulation of fatty acids. Furthermore, ephedrine, which produced no significant changes in plasma nonesterified-free fatty acids, was observed to cause cardiac lesions ${ }^{67 .}$ Nevertheless, it was found that inhibition of lipolysis by nicotinic acid, $\beta$-pyridyl carbonyl or high plasma glucose concentrations during infusion of isoproterenol could substantially reduce the increase in myocardial oxygen consumption. This may be possibly due to the prevention of 
the uncoupling action of high intracellular concentrations of free fatty acid in the heart, following catecholamine administration $^{63}$. A casual relationship between the increase in plasma-free fatty acids following norepinephrine administration and the occurrence of cardiac lesions has also been postulated ${ }^{64}$. The evidence fails to implicate elevated levels of free fatty acids as primary agents in mitochondrial uncoupling following administration of catecholamines. But it was suggested that metabolism of free fatty acids in some way aggravate the cardio toxic effects of catecholamines ${ }^{63}$ as well as the correlation of severity of lesions with the amount of body fat ${ }^{84}$.

\section{Electrolytes Shifts and Intercellular $\mathrm{Ca}^{2+}$-Overload}

In view of the close relationship between electrolyte shifts and the occurrence of necrotic lesions, it has been suggested that changes in myocardial electrolyte contents initiated by altered cationic transfer ability of myocardial cells at the plasma membrane and subcellular membrane sites by catecholamines contribute to irreversible failure of cell function ${ }^{85}$. Critical in the pathogenesis of irreversible damage was the loss of cellular $\mathrm{Mg}^{2+68}$. In this regard, it was pointed out that $\mathrm{Mg}^{2+}$ is an important activator cation participating in the function of many enzymes involved in phosphate transfer reactions, including use of ATP. Unfortunately, this mechanism cannot be considered adequate to explain the reduction of high-energy phosphate content in the myocardium $^{86}$ since interference with energy use would have the opposite effect. On the other hand, $\mathrm{Mg}^{2+}$ is reported to cause a decrease in the respiration-supported uptake of $\mathrm{Ca}^{2+}$ by isolated heart mitochondria ${ }^{87}$ and could thus be important in regulating the mitochondrial function in terms of oxidative phosphorylation. It has been similarly argued that it is the derangement of myocardial electrolyte balance, specifically the loss of $\mathrm{K}^{+}$and $\mathrm{Mg}^{2+}$ ions from the myocardium, which is the central mechanism in a variety of cardiomyopathies ${ }^{66 .}$ But this derangement of electrolyte balance was considered to be secondary to an inadequate supply of energy for transmembrane cation pumps required for the maintenance of electrolyte equilibrium, which occurs with oxygen deficiency or impaired energy production. It has also been suggested that electrolyte shifts are an important component in the development of irreversible damage produced by both direct and indirect pathogenic mechanisms, and that myocardial resistance is related to the ability of the heart to maintain a normal electrolyte balance in the face of potentially cardiotoxic episodes ${ }^{88}$. It was observed that the isoproterenol-induced necrosis and decline in high-energy phosphates were associated with a six- to sevenfold increase in the rate of radioactive $\mathrm{Ca}^{2+}$ - uptake and a doubling of net myocardial $\mathrm{Ca}^{2+}$ content ${ }^{75}$. This finding suggested that isoproterenol causes a greatly increased influx of $\mathrm{Ca}^{2+}$, which overloads the cardiomyocytes. It was postulated that the intracellular $\mathrm{Ca}^{2+}$ - overload initiates a depression in highenergy phosphate stores by excessive activation of $\mathrm{Ca}^{2+}$ dependent ATPases and impairing mitochondrial oxidative phosphorylation. This hypothesis attempts to explain why the myocardium is sensitized to isoproterenol-induced necrosis by factors, such as 9- $\alpha$-fluoro cortisol acetate, dihydrotachysterol, $\mathrm{NaH}_{2} \mathrm{PO}_{4}$, high extracellular $\mathrm{Ca}^{2+}$, or increased blood $\mathrm{pH}$, which favours intracellular $\mathrm{Ca}^{2+}$ overload. Consistent with this hypothesis, $\mathrm{K}^{+}$and $\mathrm{Mg}^{2+}$ salts, low extracellular $\mathrm{Ca}^{2+}$, thyrocalcitonin, low blood $\mathrm{pH}$, or specific blockers of transmembrane $\mathrm{Ca}^{2+}$ fluxes protect the heart against isoproterenol, presumably by preventing the occurrence of intracellular $\mathrm{Ca}^{2+}$-overload. In support of the central role for $\mathrm{Ca}^{2+}$-overload in the pathogenesis of catecholamine-induced necrosis is the observation that spontaneous necrotization of cardiac tissue in myopathic hamsters, which exhibit high levels of circulating catecholamines, is prevented by treatment with a $\mathrm{Ca}^{2+}$ channel blocker, verapamil ${ }^{89}$, 90 . It was also shown that propranolol could completely block the increase of $\mathrm{Ca}^{2+}$ content of the myocardium but would only reduce the incidence of lesions rather than preventing them. Also, necrosis of skeletal muscle fibers can be induced through mechanical injury of the cell membrane, permitting increased amount of $\mathrm{Ca}^{2+}$-influx, which can be prevented by elimination of $\mathrm{Ca}^{2+}$ from the Ringer solution or by an outward electric current, which blocks $\mathrm{Ca}^{2+}$-influx ${ }^{91}$. Unfortunately, there is no direct evidence that it is in fact $\mathrm{Ca}^{2+}$, which produces the decline of high-energy phosphate in the hearts of animals given isoproterenol and a causal relationship has not yet been established. Furthermore, it has been found that myocardial $\mathrm{Ca}^{2+}$ content increased on increasing the dose of isoproterenol in the range from 0.1 to $10 \mathrm{mg} / \mathrm{kg}$, but it did not increase further with higher dose levels required to produce myocardial lesions ${ }^{92}$. It has also been shown that increased cystolic $\mathrm{Ca}^{2+}$ in the myocytes may be due to leakage from the SR through dysfunctional ryanodine receptors ${ }^{93}$. Thus, it was suggested that the inotropic response to catecholamines is related to $\mathrm{Ca}^{2+}$ entry but that the necrosis may be due to some other factor, possibly the intracellular metabolism of $\mathrm{Ca}^{2+}$. Nonetheless, the dramatic modification of necrosis by factors influencing transmembrane $\mathrm{Ca}^{2+}$ fluxes clearly suggests the involvement of $\mathrm{Ca}^{2+}$ at some level in the etiology of necrosis caused by catecholamines ${ }^{93}$. On the basis of coincidence of localization of isoproterenol-induced myocardial lesions and the highest myocardial MAO activity, it has been suggested that the accumulation of products metabolically formed during deamination of catecholamines may be the cause of necrosis in the heart ${ }^{94 .}$ It is further pointed out that the lower sensitivity to isoproterenol may be due to the lesser MAO activity in the hearts of young rats in comparison with the older rats. These observations as well as the protective effect of monoamine oxidase inhibitors (MAOI) do not appear to be consistent with the hypothesis of intracellular $\mathrm{Ca}^{2+}$-overload. Likewise, no specific explanation has been offered for the changes in contractile proteins, which are seen to occur in catecholamine-induced necrotic lesions except for the suggestion that a direct interaction of catecholamine or some metabolite with the heavy meromyosin region of the myosin molecule is involved ${ }^{95 .}$ It is possible that MAOI may reduce the oxidation of catecholamines and thus decrease the formation of toxic substance such as free radicals and adrenochrome and subsequent myocardial necrosis. It may very well be that lysosomes ${ }^{96}$ are activated because of intracellular $\mathrm{Ca}^{2+}$-overload, and this may produce cellular damage due to catecholamines. Furthermore, catecholamines are known to markedly increase the concentration of cAMP in the heart and it is likely that this agent in high concentrations may represent an important factor for causing catecholamine-induced myocardial necrosis in association with changes due to the oxidation products of catecholamines. In summary, the majority of the factors found to influence the severity of catecholamine-induced lesions can be understood in terms of their effects on hemodynamic factors, delivery of oxygen to the myocardium, electrolyte balance, metabolism of calcium, and mobilization of lipids. It would thus appear that hemodynamic and 
coronary vascular factors contribute significantly to the severity of myocardial damage following catecholamine administration but that some primary pathogenic mechanism acting directly on the myocardial cell is probably involved as well. Furthermore, it is clear that the exhaustion of highenergy phosphate store and disruption of electrolyte balance are crucial events in the etiology of irreversible cell damage. Although mobilization of lipids and the occurrence of intracellular $\mathrm{Ca}^{2+}$-overload may be involved, the nature of the direct pathogenic influence following injection of catecholamines is yet unknown. Ultrastructural Changes shows the time -course of ultrastructural changes following isoproterenol injections in rats reported previously ${ }^{18,97}$. It has been observed that there is no correlation between mitochondrial damage and disruption of myofilaments seen 10 minutes after the isoproterenol injection, normal appearing mitochondria being found among fragmented filaments and swollen mitochondria with ruptured cristae and electrondense deposits among apparently undamaged sarcomeres ${ }^{98-}$ 101. Within 30 to 60 minutes, there also occurs a spectrum of damage to the contractile filaments, ranging from irregular bands of greater or less than normal density in sarcomeres of irregular length to fusion of sarcomeres into confluent masses and granular disintegration of the myofilaments ${ }^{102}$. The effects of norepinephrine, epinephrine, and isoproterenol are qualitatively identical at the cellular level ${ }^{103}$, with the exception that glycogen depletion ${ }^{(100)}$ and fat deposition were much more extensive with epinephrine than with isoproterenol or norepinephrine. From the foregoing discussion it appears that alterations of the contractile filaments begin with irregularities in length and misalignment of the sarcomeres, which are usually associated with an increased thickness and density of the Z-band. Contracture ensues, with the Z-bands becoming indistinct, actin and myosin filaments can no longer be distinguished. Granular disintegration of the sarcomeres follows with the appearance of large empty spaces within the muscle cells, and this fragmentation likely contributes to swelling of the cell. The tubular elements and mitochondria commence swelling soon after catecholamine injection, and the mitochondrial matrix is subsequently decreased in electron density. However, it is pointed out that swelling of the transverse tubules and sarcoplasmic reticulum (SR) is not as consistent a finding as the mitochondrial swelling and may not be evident with certain fixatives. Rupture of the cristae and deposition of electron dense material in mitochondria represent the final stage in the disruption of these organelles. Accumulation of lipid droplets and disappearance of glycogen granules is not usually evident until these other changes have occurred to some degree and are probably due to the well-known metabolic effects of catecholamines. Herniation of intercalated discs and vacuolization are probably secondary to the swelling and disruption of subcellular organelles and the disintegration of myofilaments.

\section{Membrane Changes}

By virtue of their ability to regulate $\mathrm{Ca}^{2+}$ movements in the myocardial cell, different membrane systems such as SL, SR, and mitochondria are considered to determine the status of heart function in health and disease ${ }^{104}$ Accordingly, alterations in SR, mitochondrial, and SL membranes were observed in myocardium from animals treated with high doses of catecholamines ${ }^{105}$. To investigate the role of these membrane changes in the development of contractile dysfunction and myocardial cell damage due to catecholamines, rats were injected intraperitonial with high doses of isoproterenol $(40 \mathrm{mg} / \mathrm{kg})$ and the hearts were removed at 3,9 , and 24 hours post injection ${ }^{106}$. The cardiac hypertrophy as measured by the heart or body weight ratio and depression in contractile function were seen at 9 and 24 hours, whereas varying degrees of myocardial cell damage occurred within 3 to 24 hours of isoproterenol injection. Alterations in heart membranes were evident from the fact that phospholipid contents in SL and mitochondria were increased at 3 and 9 hours, whereas the SR phospholipid contents increased at 3, 9, and 24 hours after injecting isoproterenol. It was interesting to observe that phospholipid $\mathrm{N}$-methylation, which has been shown to modulate the $\mathrm{Ca}^{2+}$ transport activities ${ }^{107}$, exhibited an increase at 3 hours and a decrease at 24 hours in both SL and SR, while no changes were observed in mitochondria. These studies ${ }^{108}$ suggest that changes in heart membranes during the development of catecholamine-induced cardiomyopathy are of crucial importance in determining the functional and structural status of the myocardium. An analysis of results described in various investigations ${ }^{109,110}$ revealed that the activity of the SL Ca ${ }^{2+}$-pump (ATP-dependent $\mathrm{Ca}^{2+}$-uptake and $\mathrm{Ca}^{2+}$ stimulated ATPase), which is concerned with the removal of $\mathrm{Ca}^{2+}$ from the cytoplasm, was increased at 3 hours and decreased at 24 hours following isoproterenol injection. On the other hand, $\mathrm{Na}^{+}$-dependent $\mathrm{Ca}^{2+}$-uptake, unlike the $\mathrm{Na}^{+}$ -induced $\mathrm{Ca}^{2+}$-release, was decreased at 3,9 , and 24 hours of isoproterenol administration. The SL ATP-independent $\mathrm{Ca}^{2+}$ binding, which is considered to reflect the status of superficial stores of $\mathrm{Ca}^{2+}$ at the cell membrane, and SL sialic acid residues, which bind $\mathrm{Ca}^{2+}$, were increased at 9 and 24 hours. These SL alterations were not associated with any changes in the nitrendipine binding (an index of $\mathrm{Ca}^{2+}$ channels), $\mathrm{Na}^{+}-\mathrm{K}^{+}$ATPase (an index of $\mathrm{Na}^{+}$-pump), and $\mathrm{Ca}^{2+} / \mathrm{Mg}^{2+}$ ecto-ATPase (an index of $\mathrm{Ca}^{2+}$-gating mechanism). An early increase in SL $\mathrm{Ca}^{2+}$-pump may help the cell to remove $\mathrm{Ca}^{2+}$, whereas depressed $\mathrm{Na}^{+}-\mathrm{Ca}^{2+}$ exchange can be seen to contribute toward the occurrence of intracellular $\mathrm{Ca}^{2+}$-overload. Likewise, an increase in the entry of $\mathrm{Ca}^{2+}$ from the elevated SL superficial $\mathrm{Ca}^{2+}$ stores as well as depressed SL $\mathrm{Ca}^{2+}$-pump may contribute toward the occurrence of intracellular $\mathrm{Ca}^{2+}$-overload at late stage catecholamine-induced cardiomyopathy. It is now well known that relaxation of the cardiac muscle is mainly determined by the activity of $\mathrm{Ca} 2^{+}$-pump located in the SR, whereas the interaction of $\mathrm{Ca}^{2+}$ with myofibrils determines the ability of myocardium to contract. On the other hand, mitochondria, which are primarily concerned with the production of ATP, are also known to accumulate $\mathrm{Ca}^{2+}$ to lower the intracellular concentration of $\mathrm{Ca}^{2+}$ under pathological conditions. Mitochondrial $\mathrm{Ca}^{2+}$-uptake, unlike mitochondrial ATPase activity, was increased at 9 and 24 hours of isoproterenol injection. Although no change in myofibrillar $\mathrm{Ca}^{2+}$-stimulated ATPase activity was apparent, the myofibrillar $\mathrm{Mg}^{2+}$ ATPase activity was depressed at 9 and 24 hours of isoproterenol injection. Time-dependent changes in the adrenergic receptor mechanisms ${ }^{111}$, which are also concerned with the regulation of $\mathrm{Ca}^{2+}$ movements in myocardium, were also seen during the development of catecholamine-induced cardiomyopathy. In particular, the number of $\beta$-adrenergic receptors was decreased at 9 hours, whereas the number of a-adrenergic receptors decreased at 24 hours of isoproterenol injection. In another study it was found that norepinephrine increased myocardial $\beta_{1}$-adrenoceptor density at one and four hours post norepinephrine 
treatment $^{112 ;}$ in contrast, chronic administration of norepinephrine for eight weeks has been shown to reduce $\beta_{1}$ adrenoceptor density ${ }^{113,114}$. The basal adenylyl cyclase activities were not changed, whereas stimulation of adenylyl cyclase by epinephrine was depressed at three and nine hours. Activation of adenylyl cyclase by a non hydrolyzable analog of guanine nucleotide ( $\mathrm{Gpp}(\mathrm{NH}) \mathrm{p})$ and $\mathrm{NaF}$ was decreased at 3,9 , and 24 hours of isoproterenol injection. Chronic infusion of isoproterenol has also been associated with an increase in cardiac $\beta$-adrenergic receptor kinase content ${ }^{115}$. Recently in another study, early changes in intracellular $\mathrm{Ca}^{2+}$-overload were observed to occur two minutes following isoproterenol injection. During the preinfarction period (before 12 hours) there was a significant increase in $\mathrm{Ca}^{2+}$ levels in cardiac mitochondrial and microsomal fractions. Enhanced mitochondrial $\mathrm{Ca}^{2+}$-uptake, decreased ryanodine binding and $\mathrm{Na}^{+} / \mathrm{Ca}^{2+}$ exchanger activity, as well as activation of PMCA and SERCA have also been reported. These changes lead to failed compensation and failed recuperation of $\mathrm{Ca}^{2+}$ dynamics during the first six hours post isoproterenol treatment ${ }^{51}$. Accordingly, it is suggested that subcellular mechanisms concerned with the regulation of $\mathrm{Ca}^{2+}$ movements are altered in catecholamine induced cardiomyopathy. In summary, it appears that some of the changes in heart membranes are adaptive in nature, whereas others contribute toward the pathogenesis of myocardial cell damage and contractile dysfunction. The early increase in SL and SR $\mathrm{Ca}^{2+}$-pump mechanisms as well as late changes in mitochondrial $\mathrm{Ca}^{2+}$ uptake seems to help the myocardial cell in lowering the intracellular concentration of $\mathrm{Ca}^{2+}$. On the other hand, the early depression in $\mathrm{SL} \mathrm{Na}{ }^{+}-\mathrm{Ca}^{2+}$ exchange and late decrease in SL and SR $\mathrm{Ca}^{2+}$-pump may lead to the development of intracellular $\mathrm{Ca}^{2+}$-overload. This change may result in the redistribution and activation of lysosomal enzymes ${ }^{116}$ and other mechanisms for the disruption of the myocardial cell due to high levels of circulating catecholamines. It should be mentioned that genes such as UCP2 and FHL1 have been identified to play a role in the development of cardiomyopathy induced by b-adrenergic signalling ${ }^{117}$. Increased protein amounts of the tumour suppressor PTEN in response to isoproterenol stimulation may negatively regulate $\mathrm{P}^{\mathrm{I} 3}$ kinase activity ${ }^{118}$. $\mathrm{P}^{\mathrm{I} 3}$ kinase $\mathrm{g}$ was found to be critical for inducing myocardial hypertrophy, interstitial fibrosis, and cardiac dysfunction in response to b-adrenergic stimulation. P110g mice, which are deficient for the catalytic subunit for pI3 kinase $\gamma$, have shown resistance to the effects of isoproterenol on cardiac structure and function; however, these animals did not show any change in the induction of hypertrophy markers in response to isoproterenol ${ }^{119}$.

\section{Histological Changes}

Histological changes in catecholamine-induced cardiomyopathy are generally characterized by degeneration and necrosis of myocardial fiber, accumulation of inflammatory cells such as leukocytes, interstitial edema, lipid droplet (fat deposition), and endocardial hemorrhage. Interstitial edema is usually associated with subendocardial and subepicardial haemorrhages following administration of catecholamines and is characteristically present in damaged areas of the myocardium even after 72 hours ${ }^{49,121}$. Interstitial edema and inflammation are much more prominent following epinephrine or norepinephrine injections even though isoproterenol is more potent in producing cellular damage ${ }^{100}$. Accordingly, it has been suggested that edema and inflammation result from mechanisms different from those causing necrotic tissue damage during the development of catecholamine- induced cardiomyopathy. Histochemical alterations subsequent to administration of lesion producing doses of catecholamines have also been reported in detail $^{100,101,103 .}$ A marked loss of glycogen is seen within 30 minutes, and is most marked following epinephrine administration. Accumulation of peroxidase acid-Schiff (PAS)-positive material is seen at one hour and in an increasing number of fibers over the next 24 hours. This is associated with loss of normal striations and appearance of clear vacuoles. A Meta chromatic substance is usually observed in areas of interstitial edema and inflammation. All three catecholamines have been shown to produce biphasic changes in the activities of different oxidative enzymes. There is a rapid increase in the activities of enzymes; this is evident within five minutes in various individual fibers, followed by a gradual decline in the activities during 6 to 12 hours. Certain areas of the myocardium having markedly diminished oxidative enzyme activities are interspersed with fibers of normal activities. Decline in oxidative enzyme activities of certain fibers progresses until frank necrosis is evident and there is complete loss of the activities. In each case the degree of change of the enzyme activities is proportional to the normal level of activity of the enzyme involved. Cytochrome oxidase activity is unchanged until evidence of early necrosis is seen after 6 to 12 hours, at which time the activity of this enzyme decreases as well. An increased number of lipid droplets are observed at 30 minutes. Fatty change is more evident in the endocardial region than elsewhere and has been reported by Ferrans et $a l{ }^{100}$ to be least apparent with epinephrine; this is in direct contradiction of the findings of Lehr et al. ${ }^{103}$. The reason for this discrepancy is not clear; however, fibers, which contain large lipid droplets, show decreased activities of the oxidative enzymes, including cytochrome oxidase. Furthermore, all three catecholamines cause a slight increase in the staining of cytoplasm for lysosomal esterase activity ${ }^{100}$. It has been reported that ATPase and acid phosphatase were also increased in norepinephrine- induced cardiomyopathy ${ }^{120}$.

\section{CONCLUSIONS}

It is well known that massive amounts of catecholamines are released from the sympathetic nerve endings and adrenal medulla under stressful situations. Initially, these hormones produce beneficial effects on the cardiovascular system to meet the energy demands of various organs in the body, and their actions on the heart are primarily mediated through the stimulation of $b$ - adrenergic receptors, $G$ protein, adenylate cyclase, and cAMP system in the myocardium. However, prolonged exposure of the heart to high levels of catecholamines results in coronary spasm, arrhythmias, contractile dysfunction, cell damage, and myocardial necrosis. Different pharmacological, hormonal, and metabolic interventions, which are known to reduce the occurrence of intracellular $\mathrm{Ca}^{2+}$ - overload, have been shown to prevent the cardiotoxic actions of catecholamines. Several mechanisms such as relative hypoxia, hemodynamic alterations, coronary insufficiency, changes in lipid mobilization and energy metabolism, electrolyte imbalance, and membrane alterations have been suggested to explain the cardiotoxic effects of high concentrations of catecholamines. Recent studies have shown that oxidation of catecholamines results in the formation of highly toxic substances such as aminochromes (e.g., adrenochrome) and free radicals and these then, by the virtue of their actions on different types of 
heart membranes, cause intracellular $\mathrm{Ca}^{2+}$-overload and myocardial cell damage. Hemodynamic and metabolic actions of catecholamines may aggravate toxic effects of the oxidation products of catecholamines. Thus, it appears that antioxidant therapy in combination with some $\mathrm{Ca}^{2+}$ antagonist and/or metabolic intervention may be most effective in preventing the catecholamine-induced cardiomyopathy.

\section{ACKNOWLEDGEMENTS}

Authors would like to thank Department of Biochemistry S.K. University, Anantapuramu, A.P, India, Department of Biochemistry, College Of Medicine And Health Sciences- Gondar (Ethiopia).

\section{REFERENCES}

1. Go AS, Mozaffarian D, Roger VL, et al. Heart disease and stroke statistics - 2013 update: a report from the American Heart Association. Circulation. 2013; 127: e6-245. http://dx.doi.org/10.1161/ CIR.0b013e31828124ad

1A. Sans S, Kesteloot H, Kromhout D. The burden of cardiovascular diseases mortality in Europe. Task Force of the European Society of Cardiology on Cardiovascular Mortality and Morbidity Statistics in Europe. Eur. Heart J. 1997; 18(8): 1231-1248. http://dx.doi.org /10.1093/oxfordjournals.eurheartj.a015434

2. Mathers C, Fat DM, Boerma JT, Organization.WH. The Global Burden of Disease: 2004 Update. Geneva, Switzerland: World Health Organization; 2008.

3. Rea TD, Eisenberg MS, Sinibaldi G, White RD. Incidence of EMStreated out-of hospital cardiac arrest in the United States. Resuscitation. 2004; 63(1):17-24. http://dx.doi.org/10.1016/j.resuscitation.2004.03.025 PMid: 15451582

4. Opie LH. The Heart: Physiology, from Cell to Circulation. $3^{\text {rd }}$ ed. Philadephia, PA: Lippincott-Raven, 1998. PMCid: 1565255

5. Ziegler K. Uber die Wirkung intravenoser Adrenalin injection auf das Gefasssystem und ihre Beziehungen zur Arterisclerose. Beitr Z Path Anat uz allg Path. 1905; 38: 229-254.

6. Pearce RM. Experimental myocarditis: A study of the histological changes following intravenous injections of adrenaline. J Exp Med 1906;8: 400-409. http://dx.doi.org/10.1084/jem.8.3.400 PMid:19867047 PMCid:2124623

7. SB Mahammad Rahmathulla, et al. Effect of Tribulus terrestris (L.) on liver in Isoproterenol-Induced Myocardial Infarction. International Journal of Research in Biochemistry and Biophysics. 2012; 2(4): 10-12.

8. Rona G, Chappel CI, Balazs T, et al. An infarct-like myocardial lesion and other toxic manifestations produced by isoproterenol in the rat. Arch Path. 1959; 67: 443-455.

9. Ostadal B, Pelouch V, Ostadalova I, et al. Structural and biochemical remodelling in catecholamine-induced cardiomyopathy: comparative and ontogenetic aspects. Mol Cell Biochem. 1995; 147: 83-88. http:// dx.doi.org/10.1007/BF00944787 PMid:7494559

10. Ostadal B, Muller E. Histochemical studies on the experimental heart infarction in the rat. Naunyn-Schmiedebergs Arch Pharmok u exp Path. 1966; 254: 439-447. http://dx.doi.org/10.1007/BF00539919

11. Sato Y, Tanaka M, Nishikawa T. Reversible catecholamine-induced cardiomyopathy by subcutaneous injections of epinephrine solution in an anesthetized patient. Anesthesiology. 2000; 92: 615-619. http:// dx.doi.org/10.1097/00000542-200002000-00048 PMid:10691253

12. Brilakis ES, Young WF, Wilson JW, et al. Reversible catecholamineinduced cardiomyopathy in a heart transplant candidate without persistent or paroxysmal hypertension. J Heart Lung Transpl. 1999; 4: 376-380. http://dx.doi.org/10.1016/S1053-2498(98)00014-X

13. Kline IK. Myocardial alterations associated with pheochromocytoma. Am J Path. 1961; 38: 539-551. PMid:13756860 PMCid:1942360

14. Szakacs JE, Dimmette RM, Cowart EC Jr. Pathologic implication of the catecholamines, epinephrine and norepinephrine. US Armed Forces Med J. 1959; 10: 908-925. PMid: 13836287

15. van Vliet PD, Burchell HB, Titus JL. Focal myocarditis associated with pheochromocytoma. New Eng J Med. 1966; 274: 1102-1108. http://dx.doi.org/10.1056/NEJM196605192742002 PMid:5932021

16. Connor RCR. Focal myocytolysis and fuchsinophilic degeneration of the myocardium of patients dying with various brain lesions. Ann N Y Acad Sci.1969;156:261-270.http://dx.doi.org/10.1111/j.17496632.1969.tb16732.x PMid:4110943

17. Greenhoot JH, Reichenbach DD. Cardiac injury and subarachnoid hemorrhage. A clinical, pathological and physiological correlation. J Neurosurg. 1969; 30: 521-526. http://dx.doi.org/10.3171/ jns. 1969.30.5.0521 PMid:5782382

18. Reichenbach DD, Benditt EP. Catecholamines and cardiomyopathy: The pathogenesis and potential importance of myofibrillar degeneration.
Human Path. 1970; 1: 125-150. http://dx.doi.org/10.1016/S00468177(70)80007-7

19. Smith RP, Tomlinson BE. Subendocardial hemorrhages associated with intra cranial lesions. J Path Bact. 1954; 68: 327-334. http:/ /dx.doi.org/10.1002/path.1700680204

20. Kaye MP, McDonald RH, Randall WC. Systolic hypertension and subendocardial hemorrhages produced by electrical stimulation of the stellate ganglion. Circ Res. 1961; 9: 1164-1170. http:/ /dx.doi.org/10.1161/01.RES.9.6.1164 PMid:14454680

21. Klouda MA, Brynjolfson G. Cardiotoxic effects of electrical stimulation of the stellate ganglia. Ann N Y Acad Sci. 1969; 156: 271-279. http:/ /dx.doi.org/10.1111/j.1749-6632.1969.tb16733.x

22. Melville KI, Garvey HL, Sluster HE, et al. Central nervous system stimulation cardiac ischemic change in monkeys. Ann N Y Acad Sci. 1969;156:241-260.http://dx.doi.org/10.1111/j.1749-6632.1969.tb1 6731.x PMid:4400974

23. Wood R, Commerford PJ, Rose AG, et al. Reversible catecholamineinduced cardiomyopathy. Am Heart J. 1991; 121: 610-613. http:// dx.doi.org/10.1016/0002-8703(91)90740-9

24. Hicks RJ, Wood B, Kalff V, et al. Normalization of left ventricular ejection fraction following resection of pheochromocytoma in a patient with dilated cardiomyopathy. Clin Nucl Med. 1991; 16: 413-416. http://dx.doi.org/10.1097/00003072-199106000-00007 PMid:1868653

25. Hamada N, Akamatsu A, Joh T. A case of phlochromocytoma complicated acute renal failure and cardiomyopathy. Jpn Circ J. 1993; 57: 84-90. http://dx.doi.org/10.1253/jcj.57.84 PMid:8437346

26. Elian D, Harpaz D, Sucher E, et al. Reversible catecholamine-induced cardiomyopathy presenting as acute pulmonary edema in a patient with pheochromocytoma. Cardiology. 1993; 83:118-120. http://dx.doi.org/10.1159/000175956 PMid:8261476

27. Powers FM, Pifarre R, Thomas JX Jr. Ventricular dysfunction in norepinephrineinduced cardiomyopathy. Circ Shock. 1994; 43:122-129. PMid:7850932

28. Boutet M, Huttner I, Rona G. Aspect microcirculatoire des lesions myocardiques provoquees par l'infusion de catecholamines, Etude ultra structural a l'aide de traceurs de diffusion, I. Isoproterenol. PathologieBiologie. 1973; 21: 811-825.

29. Boutet M, Huttner I, Rona G. Aspect microcirculatoire des lesions myocardiques provoquees par l'infusion de catecholamines. Etude ultra structural a l'aide traceurs de diffusion. II. Norepinephrine. PathologieBiologie. 1974; 22: 377-387.

30. Handforth CP. Isoproterenol-induced myocardial infarction in animals. Arch Path. 1962; 73: 161-165. PMid:13904308

31. Handforth CP. Myocardial infarction and necrotizing arteritis in hamsters produced by isoproterenol (Isuprel). Med Serv J Can. 1962; 18: 506-512. PMid:13904309

32. Rona G, Boutet M, Hutter I, et al. Pathogenesis of isoproterenol induced myocardial alterations: Functional and morphological correlates. In: Dhalla NS, ed. Recent Advances in Studies on Cardiac Structure and Metabolism. Baltimore: University Park Press; 1973. p. 507-525 PMid:4806665

33. SB Mahammad Rahmathulla, KV Sailaja, Prof Kodidhela Lakshmi Devi "Tribulus Terrestris (l) Protects Heart and Liver from Beta AdrenergicStimulated Cardiotoxicity: Biochemical and Histological study in Wistar Rats" Int. J. Drug Dev. \& Res., January-March 2013, 5(1): 264-270.

34. Maruffo CA. Fine structural study of myocardial changes induced by isoproterenol in Rhesus monkeys (Macaca mulatta). Am J Path 1967; 50: 27-37. PMid:4959633 PMCid:1965173

35. Ostadal B, Rychterova V, Poupa O. Isoproterenol-induced acute experimental cardiac necrosis in the turtle. Am Heart J. 1968; 76: 645649. http://dx.doi.org/10.1016/0002-8703(68)90163-4

36. Regan TJ, Markov A, Kahn MI, et al. Myocardial ion and lipid exchanges during ischemia and catecholamine induced necrosis: Relation to regional blood flow. In: Bajusz E, Rona G, eds. Recent Advances in Studies in Cardiac Structure and Metabolism. Baltimore: University Park Press; 1972. p. 656-664 PMid:4681491

37. Rosenblum I, Wohl A, Stein AA. Studies in cardiac necrosis I. Production of cardiac lesions with sympathomimetic amines. Toxicol ApplPharmacol.1965;7:1-8.http://dx.doi.org/10.1016/0041-008X(65) 90067-0

38. Rosenblum I, Wohl A, Stein AA. Studies in cardiac necrosis. II. Cardiovascular effects of sympathomimetic amines producing cardiac lesions. Toxicol Appl Pharmacol. 1965; 7: 9-17. http://dx.doi.org/ 10.1016/0041-008X(65)90068-2

39. Bhagat B, Sullivan JM, Fisher VW, et al. cAMP activity and isoproterenol-induced myocardial injury in rats. In: Kobayashi T, Ito Y, Rona G, eds. Recent Advances in Studies on Cardiac Structure and Metabolism. Baltimore: University Park Press; 1978. p. 465-470.

40. Todd GL, Baroldi G, Pieper GM, et al. Experimental catecholamineinduced myocardial necrosis. I. Morphology, quantification and regional 
distribution of acute contraction band lesions. J Mol Cell Cardiol. 1985; 17: 317-338. http://dx.doi.org/10.1016/S0022-2828(85)80132-2

41. Todd GL, Baroldi G, Pieper GM, et al. Experimental catecholamineinduced myocardial necrosis. II. Temperal development of isoproterenol-induced contraction band lesions correlated with ECG, hemodynamic and biochemical changes. J Mol Cell Cardiol 1985; 17: 647-656. http://dx.doi.org/10.1016/S0022-2828(85)80064-X

42. Boutet M, Huttner I, Rona G. Permeability alterations of sarcolemmal membrane in catecholamine-induced cardiac muscle cell injury. Lab Invest. 1976; 34: 482-488. PMid: 1271749

43. Todd GL, Cullan GE, Cullan GM. Isoproterenol-induced myocardial necrosis and membrane permeability alterations in the isolated perfused rabbit heart. Exp Mol Pathol. 1980; 33: 43-54. http://dx.doi.org/ 10.1016/0014-4800(80)90006-4

44. Raab W. Pathogenic significance of adrenalin and related substances in heart muscle. Exp Med Surg. 1943; 1: 188-225.

45. Rahmathulla MDSB, Prof K. Lakshmidevi, Practical Biochemistry Manual (Methods and Interpretations), LAP Lambert Academic Publishing . 2013; 25(04): 65-68.

46. Rajadurai M, Stanely Mainzen Prince P. Preventive effect of naringin on lipid peroxides and antioxidants in isoproterenol-induced cardiotoxicity in Wistar rats: biochemical and histopathological evidences. Toxicology. 2006; 228: 259-268. http://dx.doi.org/10.1016/j.tox.2006.09.005 PMid: 17084010

47. SB mahammad rahmathulla, effect of Tribulus terrestris fruit aqueous extract on hyperlipidaemia and maintenance of liver architecture in isoproterenol-induced myocardial infarction in rats. Int $\mathrm{j}$ pharm bio sci. 2013 jan; 4(1): (b) 983 - 992

48. Chappel CI, Rona G, Balazs T, et al. Severe myocardial necrosis produced by isoproterenol in the rat. Arch Int Pharmacodyn 1959; 122: 123-128. PMid: 13809254

49. Rona G, Zsoter T, Chappel C, et al. Myocardial lesions, circulatory and electro cardiographic changes produced by isoproterenol in the dog. Rev Can Biol. 1959; 18: 83-94. PMid:13646243

50. Mohan P, Bloom S. Lipolysis is an important determinant of isoproterenol-induced myocardial necrosis. Cardiovascular Pathology 1999; 8: 255-261. http://dx.doi.org/10.1016/S1054-8807(99)00017-4

51. Diaz-Munoz M, Alvarez-Perez MA, Yanez L, et al. Correlation between oxidative stress and alteration of intracellular calcium handling in isoproterenol-induced myocardial infarction. Mol Cell Biochem. 2006; 289:125-136.http://dx.doi.org/10.1007/s11010-006-9155-1 PMid: 16820956

52. Meyer R, Linz KW, Surges R, et al. Rapid modulation of L-type calcium current by acutely applied oestrogens in isolated cardiac myocytes from human, guinea pig and rat. Exp Physiol.1998; 83: 305321. PMid:9639341

53. Li HY, Bian JS, Kwan YW, et al. Enhanced responses to 17b-estradiol in rat hearts treated with isoproterenol: involvement of cyclic AMPdependent pathway. J Pharmacol Exp Ther. 2000; 293:592-598. PMid: 10773033

54. Nair PS, Devi CS. Efficacy of mangiferin on serum and heart tissue lipids in rats subjected to isoproterenol induced cardiotoxicity. Toxicology 2006; 228:135-139. http://dx.doi.org/10.1016 j.tox.2006.08.030 PMid:17052832

55. Remiao F, Carmo H, Carvalho F, et al. Copper enhances isoprotereno toxicity in isolated rat ardiomyocytes: effects on oxidative stress. Cardiovasc Toxicol 2001; 1: 195-204. http://dx.doi.org/10.1385 /CT:1:3:195

56. Higuchi Y. Changes of lipid peroxides and alpha-tocopherol in rats with experimentally induced myocardial necrosis. Acta Med Okayama. 1982; 36: 113-124. PMid:7136848

57. SB Mahammad Rahmathulla, Kodidhela Lakshmi Devi. Preventive Effect of Antioxidant Vitamins on Cardiovascular Diseases. Indian Journal of Advances in Chemical Science. 2013; 1(2): 123-131.

58. Singal PK, Dhillon KS, Beamish RE, et al. Protective effects of zinc against catecholamine- induced myocardial changes. Electrocardiographic and ultrastructural studies. Lab Invest 1981; 44: 426-433. PMid:7230729

59. Besbasi FS, Hamlin RL. Influence of phenytoin on isoproterenolinduced myocardial fibrosis in rats. Am J Vet Res. 1990; 51: 36-39. PMid:2301818

60. Manjula TS, Geetha A, Ramesh TG, et al. Reversal of changes of myocardial lipids by chronic administration of aspirin in isoproterenolinduced myocardial damage in rats. Indian J Physiol Pharmacol. 1992; 36: 47-50. PMid: 1597342

61. Kolin A, Brezina A, Mamelak M, et al. Cardioprotective action of sodium gamma hydroxybutyrate against isoproterenol induced myocardial damage. Int J Exp Pathol 1993; 74: 275-281. PMid:8334077 PMCid:2002167

62. Jasmin G. Morphologic effects of vasoactive drugs. Can J Physiol Pharamcol. 1966; 44: 367-372. http://dx.doi.org/10.1139/y66-043
63. Mjos DD. Effect of inhibition of lipolysis on myocardial oxygen consumption in the presence of isoproterenol. J Clin Invest 1971; 50: 1869-1873. http://dx.doi.org/10.1172/JCI106679 PMid:5564394 PMCid:292113

64. Hoak JC, Warner ED, Connor WE. New concept of levarterenol-induced acute myocardial ischemic injury. Arch Pathol. 1969; 87: 332-338.

65. Singal PK, Kapur N, Beamish RE, et al. Antioxidant protection against epinephrineinduced arrhythmias. In: Beamish RE, Singal PK, Dhalla NS, eds. Stress and Heart Disease. Boston: Martinus Nijhoff, 1985. http://dx.doi.org/10.1007/978-1-4613-2587-1_15 PMCid:1646263

66. Raab W. Myocardial electrolyte derangement: Crucial feature of plusicausal, socalled coronary, heart disease. Ann N Y Acad Sci 1969; 147: 627-686. http://dx.doi.org/10.1111/j.1749-6632.1969.tb41278.x PMid:4902584

67. Rosenblum I, Wohl A, Stein A. Studies in cardiac necrosis. III. Metabolic efects of sympathomimetic amines producing cardiac lesions. Toxicol Appl Pharamcol. 1965; 7: 344-351. http://dx.doi.org /10.1016/0041-008X(65)90103-1

68. Lehr D, Chau R, Kaplan J. Prevention of experimental myocardial necrosis by electrolyte solutions. In: Bajusz B, Rona G, eds. Recent Advances in Studies on Cardiac Structure and Metabolism. Baltimore: University Park Press; 1972. p. 684-698 PMid:4681494

69. Rona G, Dusek J. Studies on the mechanism of increased myocardial resistance. In: Bajusz B, Rona G, eds. Recent Advances in Studies on Cardiac Structure and Metabolism. Baltimore: University Park Press; 1972. p.422-429 PMid:4681472

70. Strubelt O, Siegers CP. Role of cardiovacular and ionic changes in pathogenesis and prevention of isoprenaline-induced cardiac necrosis. Pathophysiology and morphology of myocardial cell alteration. In: Fleckenstein A, Rona, G, eds. Recent Advances in Studies on Cardiac Structure and Metabolism. Baltimore: University Park Press; 1975. p. 135-142 PMid:741

71. Ostadal B, Poupa O. Occlusion of coronary vessels after administration of isoprenoline, adrenalin and noradrenalin. Physiol Bohemoslov. 1967; 16: $116-119$.

72. Brandi G, McGregor M. Intramural pressure in the left ventricle of the dog. Cardiovasc Res. 1969; 3: 472-475. http://dx.doi.org/10.1093 $/ \mathrm{cvr} / 3.4 .472$

73. Cutarelli R, Levy MN. Intraventricular pressure and the distribution of coronary blood flow. Circ Res 1963; 12: 322-327. http://dx.doi.org /10.1161/01.RES.12.3.322 PMid:14024388

74. Buckberg GD, Fixler DE, Archie JP, et al. Experimental subendocardial ischemia in dogs with normal coronary arteries. Circ Res 1972; 30: 6781. http://dx.doi.org/10.1161/01.RES.30.1.67 PMid:5007529

75. Buckberg GD, Ross G. Effects of isoprenaline on coronary blood flow: Its distribution and myocardial performance. Cardiovasc Res 1973; 7 429-437. http://dx.doi.org/10.1093/cvr/7.4.429 PMid:4721688

76. Bajusz E. The terminal electrolyte-shift mechanism in heart necrosis: Its significance in the pathogenesis and prevention of necrotizing cardiomyopathies. In: Bajusz E, ed. Electrolytes and Cardiovascular Diseases. Basel, Switzerland: S. Karger, 1975.

77. Raab W, van Lith $\mathrm{P}$, Lepeschkin E, et al. Catecholamine-induced myocardial hypoxia in the presence of impaired coronary dilatability independent of external cardiac work. Am J Cardiol 1962; 9: 455-470. http://dx.doi.org/10.1016/0002-9149(62)90163-7

78. Lee KS, Yu DH. Effects of epinephrine on metabolism and contraction of cat papillary muscle. Am J Physiol. 1964; 206: 525-530. PMid: 14160978

79. Wesifeldt ML, Gilmore JP. Apparent dissociation of the inotropic and O2 consumption effects of norepinephrine. Fed Proc. 1964; 23: 357 (abstr).

80. Klocke FJ, Kaiser GA, Ross J Jr., et al. Mechanism of increase of myocardial oxygen uptake produced by catecholamines. Am J Physiol. 1965; 209: 913-918. PMid:5850655

81. Challoner DR, Steinberg D. Metabolic effect of epinephrine on the QO2 of the arrested isolated perfused rat heart. Nature 1965; 205: 602-603. http://dx.doi.org/10.1038/205602b0

82. Hauge A, Oye I. The action of adrenaline in cardiac muscle. II. Effect on oxygen consumption in the asystolic perfused rat heart. Acta Physiol Scand. 1966; 68: 295-303. http://dx.doi.org/10.1111/j.17481716.1966.tb03430.x

83. Park JH, Meriwether BP, Park CR, et al. Gluthathione and ethylenediamine tetraacetate antagonism of uncoupling of oxidative phosphorylation. Biochim Biophys Acta. 1956; 22: 403-404. http:/ /dx.doi.org/10.1016/0006-3002(56)90174-3

84. Kahn DS, Rona G, Chappel CI. Isoproterenol-induced cardiac necrosis. Ann N Y Acad Sci 1969; 156: 285-293. http://dx.doi.org/10.1111 /j.1749-6632.1969.tb16735.x PMid:5291138

85. Lehr D. Tissue electrolyte alteration in disseminated myocardial necrosis. Ann N Y Acad Sci 1969; 156: 344-378. http://dx.doi.org/ 10.1111/j.1749-6632.1969.tb16739.x PMid:5291140 
86. Fleckenstein A, Janke J, Doering HJ. Myocardial fiber necrosis due to intracellular Ca-overload. A new principle in cardaic pathophysiology. In: Dhalla NS, ed. Recent Advances in Studies on Cardiac Structure and Metabolism. Baltimore: University Park Press; 1974. p. 563-580 PMid:4468468

87. Sordahl LA, Sliver BB. Pathological accumulation of calcium by mitochondria: Modulation by magnesium. In: Fleckenstein A, Rona G, eds. Recent Advances in Studies on Cardiac Structure and Metabolism. Baltimore: University Park Press; 1975. p. 85-93 PMid:1197903

88. Lossnitzer K, Janke J, Hein B, et al. Disturbed myocardial calcium metabolism: A possible pathogenetic factor in the hereditary cardiomyopathy of the Syrian hamster. In: Fleckenstein A, Rona G, eds. Recent Advances in Studies on Cardiac Structure and Metabolism. Baltimore: University Park Press; 1975. p. 207-217 PMid:1197882

89. Bajusz E. The terminal electrolyte-shift mechanism in heart necrosis: Its significance in the pathogenesis and prevention of necrotizing cardiomyopathies. In: Bajusz E, ed. Electrolytes and Cardiovascular Diseases. Basel, Switzerland: S. Karger, 1975.

90. Jasmin G, Bajusz E. Prevention of myocardial degeneration in hamster with hereditary cardiomyopathy. In: Fleckenstein A, Rona G, eds. Recent Advances in Studies on Cardiac Structure and Metabolism. Baltimore: University Park Press; 1975. p. 219-229 PMid:1197884

91. Fleckenstein A, Janke J, Doering HJ, et al. Key role of Ca in the production of noncoronarogenic myocardial necroses. In: Recent Advances in Studies on Cardiac Structure and Metabolism. Baltimore: University Park Press; 1975. p. 21-32 PMid:1197883

92. Bloom S, Davis D. Isoproterenol myocytolysis and myocardial calcium. In: Dhalla NS, ed. Recent Advances in Studies on Cardiac Structure and Metabolism. Baltimore: University Park Press; 1974. p. 581-590 PMid:4468469

93. Ellison G, Torella D, Karakikes I, et al. Acute beta-adrenergic overload produces myocyte damage through calcium leakage from the ryanodine receptor 2(RyR2) but spares cardiac stem cells. J Bio Chem. 2007; 282: 11397-11407.http://dx.doi.org/10.1074/jbc.M607391200 PMid:17237229 PMCid:2276680

94. Muller E. Histochemical studies on the experimental heart infarction in the rat. Naunyn-Schmiedebergs Arch Pharmok u exp Path 1966; 254: $439-447$

95. Pelouch V, Deyl Z, and Poupa O. Myosin aggregation in cardaic necrosis induced by isoproterenol in rats. Physiol Bohemoslov. 1970; 19: 9-13. PMid:4283668

96. Roman S, Kutryk MJB, Beamish RE, et al. Lysosomal changes during the development of catecholamine-induced cardiomyopathy. In Beamish RE, Panagia V, Dhalla NS, eds. Pathogenesis of Stress-induced Heart Disease. Boston: Martinus Nijhoff; 1985. p. 270-280 http:// dx.doi.org/10.1007/978-1-4613-2589-5 23

97. Ferrans VJ, Hibbs RG, Black WC, et al. Isoproterenol-induced myocardial necrosis. A histochemical and electron microscopic study. Am Heart J. 1964; 68: 71-90. http://dx.doi.org/10.1016/0002 8703(64)90242-X

98. Csapa Z, Dusek J, Rona G. Early alterations of cardiac muscle cells in isoproterenol induced necrosis. Arch Path. 1972; 93: 356-365.

99. Kutsuna F. Electron microscopic studies on isoproterenol-induced myocardial lesions in rats. Jap Heart J. 1972; 13: 168-175. http: /dx.doi.org/10.1536/ihj.13.168 PMid:4537348

100.Ferrans VJ, Hibbs RG, Walsh JJ, et al. Histochemical and electron mircorsopic studies on the cardiac necrosis produced by sympathomimetic agents. Ann N Y Acad Sci. 1969; 156: 309-332. http://dx.doi.org/10.1111/j.1749-6632.1969.tb16737.x PMid:5291139

101.Ferrans VJ, Hibbs RG, Black WC, et al. Isoproterenol-induced myocardial necrosis. A Histochemical and electron microscopic study. Am Heart J. 1964; 68: 71-90. http://dx.doi.org/10.1016/00028703(64) $90242-X$

102. Bloom S, Cancilla PA. Myoctyolysis and mitochondrial calcification in rat myocardium after low doses of isoproterenol. Am J Path 1969; 54 373-391. PMid:5774264 PMCid:2013487

103.Lehr D, Krukowshi M, Chau R. Acute myocardial injury produced by sympathomimetic animes. Israel J Med Sci. 1969; 5: 519-524. PMid:5820469

104.Dhalla NS, Ziegelhoffer A, Harrow JAC. Regulation role of membrane systems in heart function. Can J Physiol Pharmacol 1977; 55: 12111234. http://dx.doi.org/10.1139/y77-167 PMid:23210

105. Varley KG, Dhalla NS. Excitation-contraction coupling in heart. XII. Subcellular calcium transport in isoproterenol-induced myocardial necrosis. Exptl Mol Pathol. 1973; 19: 94-105. http://dx.doi.org/ 10.1016/0014-4800(73)90043-9

106.Dhalla NS, Dzurba A, Pierce GN, et al. Membrane changes in myocardium during catecholamine-induced pathological hypertrophy. In: Alpert NR, ed. Perspectives in Cardiovascular Research. New York, NY: Raven Press; 1983. p. 527-534

107.Okumura K, Panagia V, Beamish RE. Biphasic changes in the sarcolemmal hopshatidylethanolamine $\mathrm{N}$-methylation in catecholamineinduced cardiomyopathy. J Mol Cell Cardiol. 1987; 19: 357-366. http:// dx.doi.org/10.1016/S0022-2828(87)80581-3

108.Dhalla NS, Ganguly PK, Panagia V, et al. Catecholamine-induced cardiomyopathy: Alterations in $\mathrm{Ca}^{2+}$ transport systems. In: Kawai $\mathrm{C}$, Abelman WH, eds. Pathogenesis of Myocarditis and Cardiomyopathy. Tokyo: University of Tokyo Press; 1987. p. 35-147

109. Makino N, Jasmin G, Beamish RE, et al. Sarcolemmal $\mathrm{Na}^{+-} \mathrm{Ca}^{2+}$ exchange during the development of genetically determined cardiomyopathy. Biochem Biophys Res Commun 1985; 133: 491-497. http://dx.doi.org/10.1016/0006-291X(85)90933-7

110.Panagia V, Elimban V, Heyliger CE, et al. Sarcolemmal alterations during catecholamine induced cardiomyopathy. In: Beamish RE, Panagia V, Dhalla NS, eds. Pathogenesis of Stress-induced Heart Disease. Boston: Martinus Nijhoff ; 1985. p. 121-131 http:/ /dx.doi.org/10.1007/978-1-4613-2589-5_11

111.Corder DW, Heyliger CE, Beamish RE, et al. Defect in the adrenergic receptoradenylate cyclase system during development of catecholamineinduced cardiomyopathy. Am Heart J 1984; 107: 537-542. http:// dx.doi.org/10.1016/0002-8703(84)90097-8

112. Neri M, Cerretani D, Fiaschi A, et al. Correlation between cardiac oxidative stress and myocardial pathology due to acute and chronic norepinephrine administration in rats. J Cell Mol Med. 2007; 11:156170.http://dx.doi.org/10.1111/j.1582-4934.2007.00009.x PMid: 17367510

113.Vatner DE, Vatner SF, Nejima J, et al. Chronic norepinephrine elicits desensitization by uncoupling the beta-receptor. J Clin Invest 1989; 84:1741-1748. http://dx.doi.org/10.1172/JCI114357 PMid:2556443 PMCid:304050

114.Dong E, Yatani A, Mohan A, et al. Myocardial beta-adrenoceptor downregulation by norepinephrine is linked to reduced norepinephrine uptake activity. Eur J Pharmacol. 1999; 384:17-24. http://dx.doi.org 10.1016/S0014-2999(99)00652-4

115. Iaccarino G, Tomhave ED, Lefkowitz RJ, et al. Reciprocal in vivo regulation of myocardial $\mathrm{G}$ protein-coupled receptor kinase expression by beta-adrenergic receptor stimulation and blockade. Circulation. 1998; 98:1783-1789.http://dx.doi.org/10.1161/01.CIR.98.17.1783 PMid:978883

116.Roman S, Kutryk MJB, Beamish RE, et al. Lysosomal changes during the development of catecholamine-induced cardiomyopathy. In: Beamish RE, Panagia V, Dhalla NS, eds. Pathogenesis of Stress-induced Heart Disease. Boston: Martinus Nijhoff; 1985. p. 270-280 http:/ /dx.doi.org/10.1007/978-1-4613-2589-5 23

117.Vatner SF, Millard RW, Patrick TA, et al. Effects of isoproterenol on regional myocardial function, electrogram, and blood flow in conscious dogs with myocardial ischemia. J Clin Invest. 1976; 57:1261-1271. http://dx.doi.org/10.1172/JCI108394 PMid:1262470 PMCid:436779

118. Crackower MA, Oudit GY, Kozieradzki I, et al. Regulation of myocardial contractility and cell size by distinct PI3K-PTEN signaling pathways. Cell. 2002; 110: 737-749. http://dx.doi.org/10.1016/S00928674(02)00969-8

119. Oudit GY, Crackower MA, Eriksson U, et al. Phosphoinositide 3-kinase gamma deficient mice are protected from isoproterenol-induced heart failure. Circulation. 2003; 108: 2147-2152. http://dx.doi.org/10.1161/ 01.CIR.0000091403.62293.2B PMid:1296363

120.Khullar M, Datta BN, Wahi PL, et al. Catecholamine-induced experimental cardiomyopathy- a histopathological, histochemial and ultrastructural study. Indian Heart J. 1989; 41: 307-313. PMid:2599540

121. Schenk EA, Moss AJ. Cardiovascular effects of sustained norepinephrine infusions. II. Morphology. Circ Res .1966; 18: 605-615. http://dx.doi.org/10.1161/01.RES.18.5.605

\section{Cite this article as:}

Mahammad Rahmathulla S. B, Kodidhela Lakshmi Devi. Origination and development of isoproterenol-induced myocardial infarction in male wistar rats. Int. Res. J. Pharm. 2013; 4(5):26-35 